\title{
Characterization and toxicity evaluation of degradation products of febantel
}

\author{
Anand A. Mahajan ${ }^{1}$, Amey M. Marathe ${ }^{2}$, Suvarna S. Jarande ${ }^{2}$, Raghuvir Pissurlenkar ${ }^{1}$ and Vandana T. Gawande ${ }^{2^{*}}$ (D)
}

\begin{abstract}
Background: The aim of the present work was to determine potential toxicity of degradation products of febantel generated under different stress conditions mentioned in guideline Q1A (R2) laid down by International Council for Harmonization (ICH). The stability behavior of febantel was studied by subjecting it to hydrolytic, oxidative, photolytic and thermal forced degradation conditions.

Results: Five degradation products (DPs) were observed which were resolved using high-performance liquid chromatography (HPLC) and characterized by LC-MS/MS using positive mode of electrospray ionization. The chromatographic separation was carried out on Hypersil ${ }^{\oplus D S}$ C18 $(150 \times 4.6$ mm, $5 \mu \mathrm{m})$ column. Optimum resolution was obtained using ammonium formate buffer $(10 \mathrm{mM}, \mathrm{pH} 3.5)$ and acetonitrile programmed in gradient elution mode at $281.0 \mathrm{~nm}$ using photodiode array detector.

Conclusion: The drug was found susceptible to degradation under all the stress conditions except thermal and oxidative stress. Five major unknown degradation products DP-I, DP-II, DP-III, DP-IV, and DP-V generated under photolytic, alkali, and acidic stress condition were identified and characterized by LC-MS/MS. The drug and identified degradation products were screened for prediction of in-silico toxicity using software viz. Swiss ADME, OSIRIS Property Explorer and Pro Tox II which indicated overall no toxicological concerns.
\end{abstract}

Keywords: High-pressure liquid chromatography, Mass spectroscopy, Resolution, Febantel, Stability

\section{Background}

Febantel is a broad spectrum veterinary anthelmintic. It is chemically designated as $2^{\prime}$-(2,3-bis(methoxycarbonyl)guanidino)-5' -phenylthio-2-methoxyacetanilide, and is active against wide range of gastrointestinal parasites in ruminants. It belongs to chemical class of benzimidazole (Fig. 1).

It is official in Indian Pharmacopoeia [1] and European Pharmacopoeia [2]. It is also included in Martindale: The Complete Drug Reference [3]. Febantel is a prodrug; after oral administration, it gets transformed into active metabolite fenbendazole by hydrolytic removal of methoxy acetyl group and subsequent cyclization; febantel is also called as probenzimidazole $[4,5]$.

\footnotetext{
* Correspondence: gawandevandana848@gmail.com

${ }^{2}$ Department of Pharmaceutical Chemistry, Sinhgad Institute of Pharmacy, Narhe, Pune 411041, Maharashtra, India

Full list of author information is available at the end of the article
}

The metabolic pathway of febantel shows that it gets converted directly to either fenbendazole or oxfendazole, which is achieved via febantel sulfoxide as an intermediate [6]. Febendazole, fenbendazole sulfone, oxfendazole, and oxfendazole sulfone are the main metabolites of febantel [7]. Generally, febantel is administered in combination with other benzimidazoles viz. pyrantel and praziquantel. Many analytical and bioanalytical methods have been reported in literature for determination of febantel alone or in combination with other benzimidazoles. Literature shows few HPLC methods for quantification of febantel from veterinary preparations $[8,9]$, feeds $[10]$. There are liquid chromatographic methods for determination of febantel in biological matrices [11-15] and fate of anthelmintics in environment $[16,17]$. Various assay methods are also available based on determination by LC and GCMS [18], HPLC-MS/MS [19-21], UV spectrophotometry $[22,23]$, IR, thermogravimetry, and scanning electron 


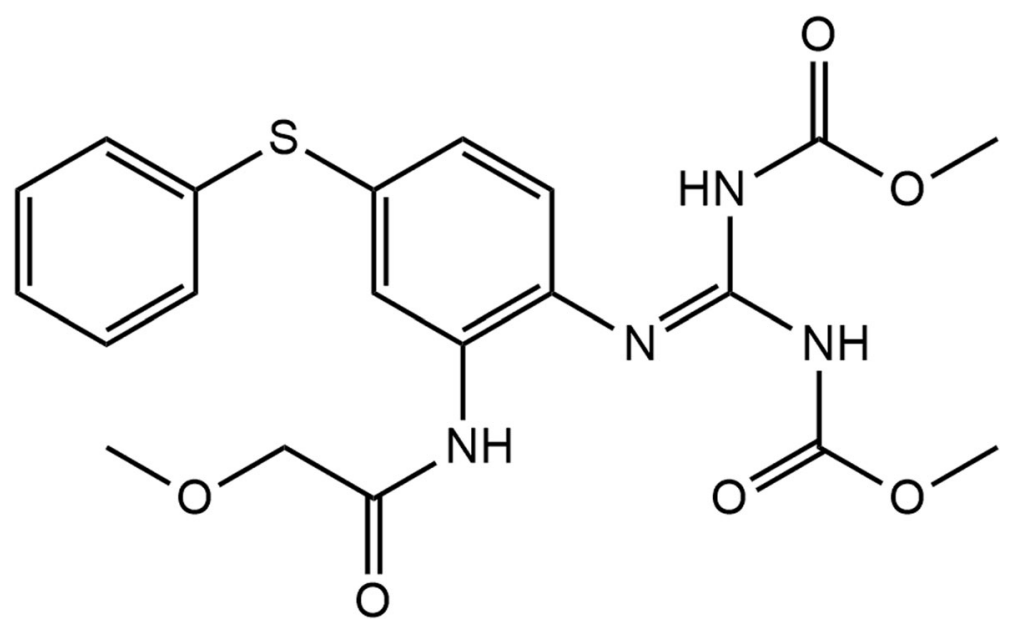

Fig. 1 Structure of febantel

microscopy [24, 25]. Little information is available on study involving photodegradation $[26,27]$ and biodegradation [28] of febantel.

Anthelmintics like febantel are widely used in animals; most of the time, the drug gets excreted unchanged in urine as well as feces and gets contaminated in water, soil, and biota. Later, these drugs undergo bio, chemical, and photodegradation which leads to formation of different products. Babic et al. in 2018 studied abiotic elimination processes of hydrolysis, photolysis, sorption of febantel, and its aquatic toxicity against luminescence bacteria Vibrio fischeri. They identified fenbendazole and fenbendazole sulfone as major degradation products by using high-resolution mass spectroscopy. They also evaluated aquatic toxicity of febantel and its hydrolytic mixture toward the luminescence bacteria Vibrio fischeri [17]. Such few reports are published related to anthelmintics, their metabolic transformation, and related toxicity, but there are no reports available where febantel is subjected to $\mathrm{ICH}$ recommended stress conditions for mimicking environmental stress conditions and where potential toxicity of degradation products is determined. Hence, the present work is addressed considering toxicological concern. Such studies are needed to develop stability indicating analytical method for analysis of stability samples and establishing shelf life. Here, we report identification of few previously unreported degradation products and their toxicity data.

\section{Methods}

\section{Chemicals and reagents}

Febantel pure drug was obtained as a gift from Veritas India Ltd. along with certificate of analysis. HPLC grade acetonitrile $(\mathrm{ACN})$, methanol $\left(\mathrm{CH}_{3} \mathrm{OH}\right)$, and formic acid $(\mathrm{HCOOH})$ were purchased from Merck, Mumbai, India and Research Lab, Mumbai, India respectively. Sodium hydroxide $(\mathrm{NaOH})$, ammonium formate $\left(\mathrm{NH}_{4} \mathrm{HCO}_{2}\right)$, and hydrochloric acid $(\mathrm{HCl})$ were purchased from Qualigens Fine Chemicals Mahape, India, and all were of analytical reagent (AR) grade. Hydrogen peroxide (30\%) was purchased from S. D. Fine Chemical Ltd, Mumbai, India. HPLC grade water was obtained from in house all glass double distillation assembly (Lab Sil Instrument, Bangalore, India).

\section{Instrumentation}

A constant temperature water bath (Intex, FRNW-326) was used for carrying out all degradation studies. For solid state thermal stress studies, a hot air oven (250BSS Pathak, Mumbai, India) was used. Photostability chamber from Newtronics Lifecare Pvt. Ltd., Mumbai, India was employed for $\mathrm{ICH}$ recommended light exposure studies. Electronic balance (CB-50 Contech, Navi Mumbai, India) was used for weighing. High-performance liquid chromatography system SPD-M20A from Shimadzu Kyoto, Japan, system having binary pump (LC-20AD), on-line degasser, $20 \mu \mathrm{L}$ injection loop, prominence diode array detector (DAD), and LC solution software on DELL computer. LCMS/MS studies were performed using Surveyor Plus HPLC System with LCQ Fleet and TSQ Quantum Access mass spectrometer from Thermo Fisher Scientific (San Jose, CA, USA). MS spectra were generated in positive mode using electrospray ionization (+ ESI) in the range of $100-1000 \mathrm{~m} / \mathrm{z}$.

Chromatographic separation was performed on Hypersil $^{\odot}$ BDS C18 $(150 \times 4.6 \mathrm{~mm}, 5 \mu \mathrm{m})$ column employing mixture of ammonium formate buffer (10 mM, pH 3.5) and acetonitrile as mobile phase. Elution was carried out in linear gradient mode and flow rate was $1.0 \mathrm{~mL} \mathrm{~min}{ }^{-1}$. Detection was carried out at $281.0 \mathrm{~nm}$ using photodiode array detector. 
The $\mathrm{pH}$ meter from Controlled Dynamics, Vadodara, Gujarat, India and sonicator from Spectralab UCB 30, Mumbai, Maharashtra, India were used for $\mathrm{pH}$ adjustment and sonication respectively.

\section{Stress studies}

The stability of febantel was determined as per guidance given under ICH Q 1A (R2) [29] in order to mimic effect of variety of environmental factors on stability of febantel. The drug was subjected to various stress conditions like hydrolysis, oxidation, photolysis, and dry heat in order to degrade the drug to $15-20 \%$. PDA detector was set at wavelength of $281.0 \mathrm{~nm}$. The degradation products were subjected to LC-MS/MS for characterization.

A stock solution $\left(1000 \mu \mathrm{g} \mathrm{mL} \mathrm{m}^{-1}\right)$ of febantel was prepared using HPLC grade acetonitrile to carry out hydrolytic, oxidative, and photolytic degradation; the drug as such was subjected for thermal degradation by placing appropriate amount of drug in sealed ampoule.

Hydrolytic degradation was carried out separately in acidic, basic, and neutral conditions. Degradation samples were prepared by mixing $1 \mathrm{~mL}$ of stock solution of drug having concentration $1000 \mu \mathrm{g} \mathrm{mL}^{-1}$ with $1 \mathrm{~mL}$ of stressor $(0.1 \mathrm{~N} \mathrm{HCl}, 0.1 \mathrm{~N} \mathrm{NaOH}$ and water) in a separate $10 \mathrm{~mL}$ volumetric flask. After exposure of $2.5 \mathrm{~h}$, acidic and alkaline stress samples were neutralized using either $0.1 \mathrm{~N} \mathrm{HCl}$ or $0.1 \mathrm{~N} \mathrm{NaOH}$ whichever needed. Finally, volume was made up to $10 \mathrm{~mL}$ with the diluent and injected in stabilized HPLC system.

For oxidative degradation with hydrogen peroxide, 1 $\mathrm{mL}$ from the stock solution of strength $1000 \mu \mathrm{g} \mathrm{mL}$ was mixed with $1 \mathrm{~mL}$ each of 15,20 , and $30 \%$ hydrogen peroxide in separate $10 \mathrm{~mL}$ volumetric flasks. Upon exposure of $24 \mathrm{~h}$, volume was made up to $10 \mathrm{~mL}$ with the diluent and injected in stabilized HPLC system.

In case of thermal degradation, $10 \mathrm{mg}$ of febantel in sealed glass ampoules was kept in hot air oven at temperature $70{ }^{\circ} \mathrm{C}$ for $2,4,6$, and 8 days. A control was also maintained at room temperature without exposure to heat.

During photo degradation, solid drug kept in petri dish and solution of drug having concentration $100 \mu \mathrm{g} \mathrm{mL}$ kept in $10 \mathrm{~mL}$ volumetric flask was exposed to $\mathrm{ICH}$ recommended dose [30] of light in photo stability chamber (overall illumination of not less than 1.2 million lux hours and an integrated near ultraviolet energy not less than 200 Watt hours/square meter) up to 4 days. In the same way, control was also maintained by wrapping samples in aluminum foil. After respective dilutions, solutions were subjected to HPLC analysis. Optimized stress conditions are provided in Table 1.

\section{Preparation of samples for HPLC analysis}

The stock solution of febantel was prepared by initially dissolving $100 \mathrm{mg}$ of febantel in $25 \mathrm{~mL}$ acetonitrile in a $100 \mathrm{~mL}$ capacity volumetric flask. After complete dissolution of drug, volume was made up to the mark with acetonitrile to obtain concentration of $1000 \mu \mathrm{g} \mathrm{mL}^{-1}$.

The diluent was prepared by mixing acetonitrile with ammonium formate buffer $(\mathrm{pH} 3.5$, adjusted using formic acid; $0.01 \mathrm{M})$ in the ratio 50:50 (v/v).

Samples which were exposed to hydrolytic stress, oxidation, and photolysis in solution state were all diluted up to the mark of $10 \mathrm{~mL}$ with the above-mentioned diluent to achieve predecided concentration $\left(100 \mu \mathrm{g} \mathrm{mL}{ }^{-1}\right)$ of febantel. While samples exposed in solid state to photolytic and thermal stress conditions were weighed and diluted appropriately with the diluent to get $100 \mu \mathrm{g}$ $\mathrm{mL}^{--1}$ concentration of febantel.

\section{HPLC method development}

Febantel has a pKa value of 5.81 and majority of the reported HPLC methods are developed using C 18 column and mixtures of methanol and/or $\mathrm{ACN}$ in combination along with buffers maintained at the $\mathrm{pH} 3$ or 7 . In present study, efforts were made to develop simple HPLC method by using combination of acetonitrile and ammonium format buffer $(10 \mathrm{mM}, \mathrm{pH}$ adjusted to 3.5 with formic acid) as mobile phase. Various attempts were made to achieve better separation among degradation products and between drug and degradation products using Thermo BDS HYPERSIL C18 (150 mm × 4.6 $\mathrm{mm}$ id, $5 \mu \mathrm{m}$ ) column as stationary phase. The detection was carried out at $281.0 \mathrm{~nm}$ at a flow rate of $1.0 \mathrm{~mL}$ $\mathrm{min}^{-1}$. At the beginning, individual stressed samples were subjected to HPLC analysis followed by analysis of

Table 1 Optimized stress conditions for degradation of febantel

\begin{tabular}{|c|c|c|c|}
\hline Stress condition & Concentration of stressor & Exposure condition & Duration \\
\hline \multicolumn{4}{|l|}{ Hydrolysis } \\
\hline Acid & $\mathrm{HCl}(0.1 \mathrm{~N})$ & $\mathrm{RT}^{\mathrm{a}}$ & $2.5 \mathrm{~h}$ \\
\hline Base & $\mathrm{NaOH}(0.1 \mathrm{~N})$ & $\mathrm{RT}^{\mathrm{a}}$ & $2.5 \mathrm{~h}$ \\
\hline Oxidation & $\mathrm{H}_{2} \mathrm{O}_{2}(30 \%)$ & $\mathrm{RT}^{\mathrm{a}}$ & $24.0 \mathrm{~h}$ \\
\hline Photolysis & Fluorescent light 1.2 million lux hours and UV light $200 \mathrm{Whm}^{-2}$ & & \\
\hline Thermal & & $70^{\circ} \mathrm{C}$ & 8.0 days \\
\hline
\end{tabular}




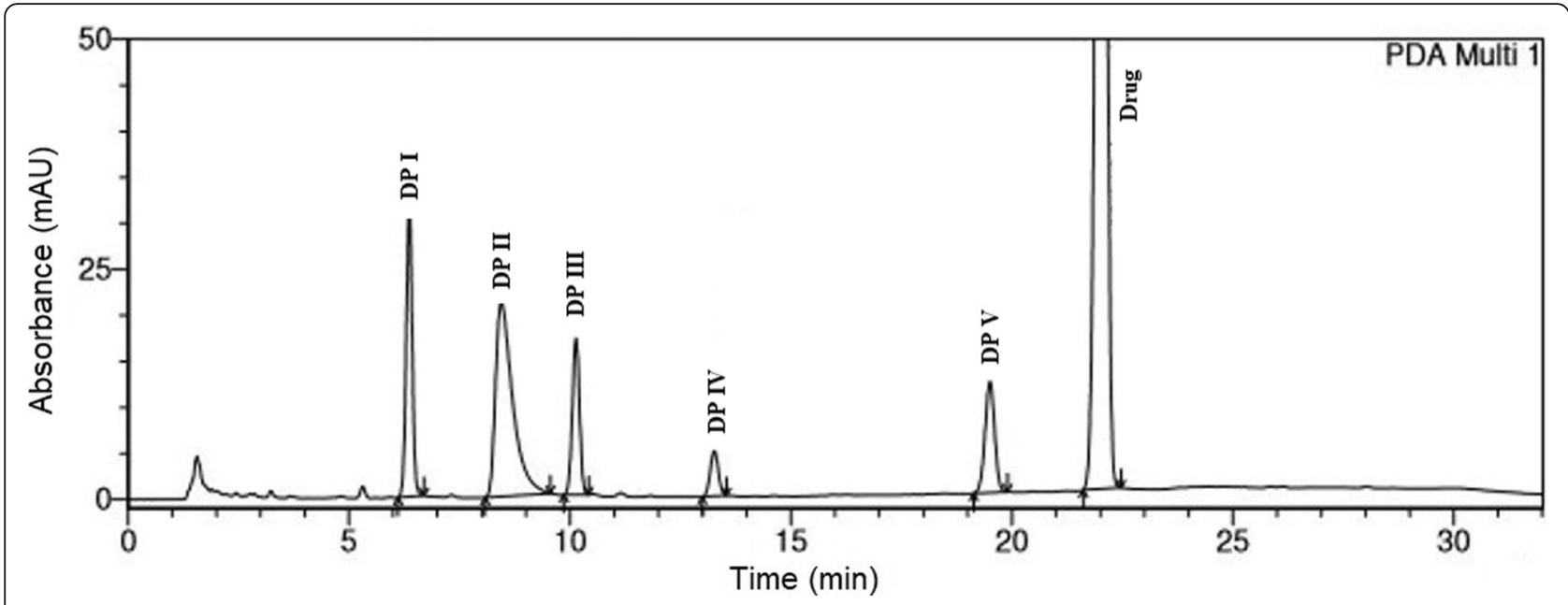

Fig. 2 Chromatogram showing separation of febantel and its degradation products (DP I, II, III, IV, and V in order of elution)

their mixture. Equal amount of each degradation sample $(1 \mathrm{~mL})$ generated during various stress conditions was mixed to produce degradation mixture (DM) and was subjected to analysis by the developed RP-HPLC method. Accordingly, method was optimized further to obtain better separation of all peaks from each other and from peak of the drug (see electronic Supplementary material Figures S1-S9).

\section{HPLC method validation}

Validation of optimized HPLC method was carried out with respect to parameters recommended under ICH Q2 (R1) guideline [31].

\section{Specificity and selectivity}

The specificity of the method was determined through establishment of resolution factor among the peaks of the degradation products and between drug peak and nearest resolving peaks. Selectivity was proved through peak purity values obtained from PDA detector.

\section{Linearity and range}

Linearity of the method was established by preparing a calibration curve. Stock solution of drug was diluted with diluent to obtain six concentrations in the range of 50-500 $\mu \mathrm{g} \mathrm{mL} \mathrm{m}^{-1}$. Each of these concentrations were injected in triplicate into the HPLC using $20 \mu \mathrm{L}$ injection loop. The peak area versus concentration was plotted to construct calibration plot and the correlation coefficient was calculated.

\section{Precision}

Intra-day and inter-day precision of the method was established by making triplicate injections of three samples prepared at three different concentration levels, i.e., 200, 300, and $400 \mu \mathrm{g} \mathrm{mL}^{-1}$ on same day and on different days. Standard deviation and relative standard deviation (\% RSD) were calculated in intra-day as well as inter-day precision studies.

\section{Accuracy}

Accuracy of the presented method was assessed through standard addition approach. Known concentrations (in triplicate) of the drug at three levels 200, 300, and 400 $\mu \mathrm{g} \mathrm{mL} \mathrm{m}^{-1}$ were spiked separately into mixture of degradation products and then percent recovery of the added drug was calculated.

\section{LC-MS studies on drug and degradation products}

The mass spectra of the drug and degradation products were recorded in positive as well as negative mode using electrospray ionization (ESI) in the mass range 100 to $1000 \mathrm{~m} / \mathrm{z}$. For optimized MS parameters, see Electronic

Table 2 Retention time, relative retention time, and peak purity data of febantel and its degradation products

\begin{tabular}{llll}
\hline Drug/degradation products & Retention time (RT) $(\mathbf{m i n})$ & Relative retention time (RRT) & Peak purity (>0.999) \\
\hline Drug (febantel) & 22.01 & 1.00 & 0.9999 \\
DP I (Photo degradation product) & 06.35 & 0.28 & 0.9999 \\
DP II (Alkali degradation product I) & 08.44 & 0.41 & 0.9999 \\
DP III (Acid degradation product I) & 10.13 & 0.45 & 0.9998 \\
DP IV (Alkali degradation product II) & 13.26 & 0.60 & 0.9994 \\
DP V (Acid degradation product II) & 19.49 & 0.33 & 0.9997 \\
\hline
\end{tabular}




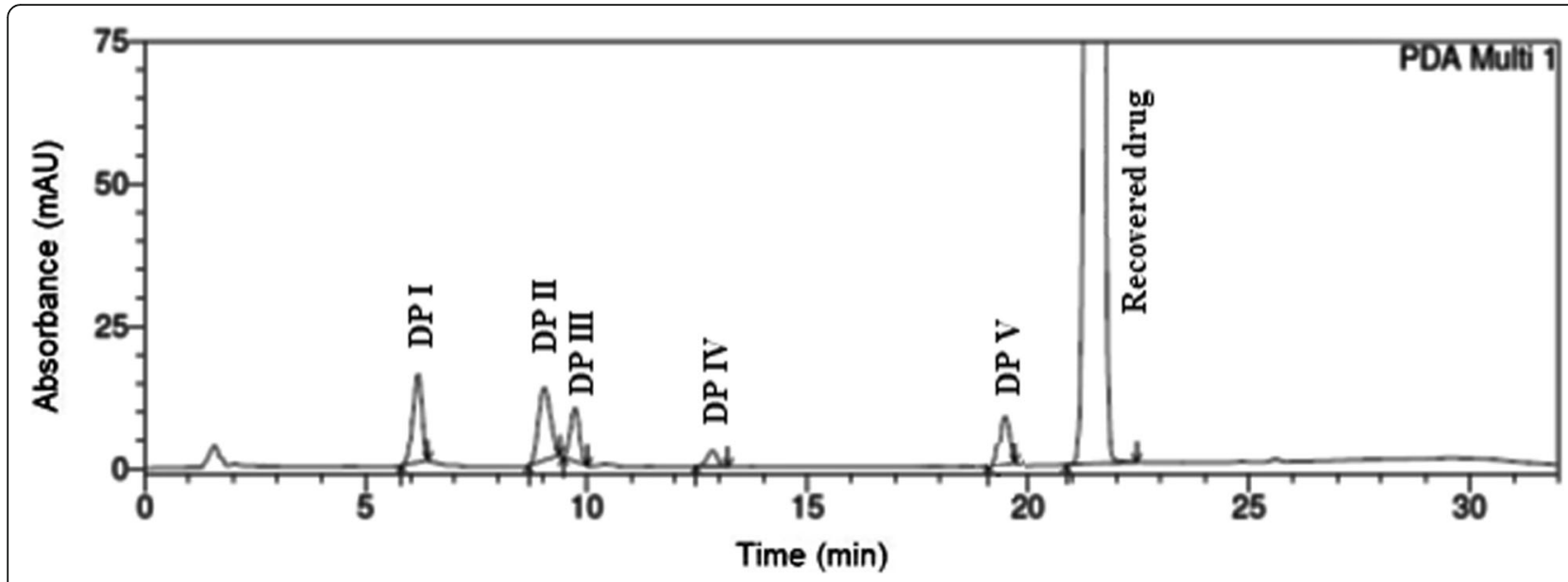

Fig. 3 Chromatogram of accuracy study at spiked concentration of febantel $300\left(\mu \mathrm{g} \mathrm{mL}^{-1}\right)$

Supplementary material Table S1. The drug solution of concentration $10 \mu \mathrm{g} \mathrm{mL} \mathrm{m}^{-1}$ (in acetonitrile) was directly injected via syringe pump into mass spectrometer. The instrument parameters were adjusted to first to locate molecular ion peak and afterwards to obtain fragmentation of the drug.

Later, the mixture of degradation samples was subjected to LC-MS and LC-MS/MS studies using optimized parameters which were used for the drug. Molecular mass of five major degradation products were recorded and subjected to mass fragmentation to elucidate chemical structure.

\section{In-silico toxicity studies}

The drug and five major degradation products (DP-I, DP-II, DP-III, DP-IV, and DP-V) formed under photolytic and hydrolytic (acid, alkali) stress conditions were subjected for in-silico ADME and toxicity predications using different models viz. Swiss ADME, OSIRIS Property Explorer, and Pro Tox II Predictions to ascertain their potential toxicity.

\section{Results}

Degradation behavior

The degradation behavior of febantel can be understood from the chromatogram shown in Fig. 2.

\section{Development and optimization of stability indicating assay method (SIAM)}

Optimum resolution separation was obtained by using mixture of acetonitrile (A) and $10 \mathrm{mM}$ ammonium

Table 3 Summary of method validation parameters

\begin{tabular}{|c|c|c|}
\hline \multicolumn{2}{|c|}{ Validation parameter } & \multirow{2}{*}{$\begin{array}{l}\text { Obtained result } \\
{ }^{a} y=39937 x+94778\end{array}$} \\
\hline Linearity & Equation of regression line & \\
\hline & $r^{2}$ & 0.9996 \\
\hline & Range $\left(\mu \mathrm{g} \mathrm{mL}^{-1}\right)$ & $50-500$ \\
\hline \multirow[t]{4}{*}{ Precision } & Actual conc. $\left(\mu \mathrm{g} \mathrm{mL^{-1 } )}\right.$ & 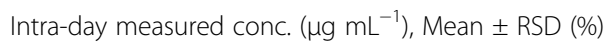 \\
\hline & $\begin{array}{l}200.00 \\
300.00 \\
400.00\end{array}$ & $\begin{array}{l}201.73 \pm 0.47 \\
300.93 \pm 0.33 \\
400.53 \pm 0.18\end{array}$ \\
\hline & Actual conc. $\left(\mu \mathrm{g} \mathrm{mL}^{-1}\right)$ & 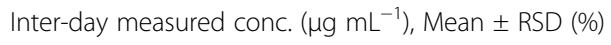 \\
\hline & $\begin{array}{l}200.00 \\
300.00 \\
400.00\end{array}$ & $\begin{array}{l}202.3 \pm 01.2 \\
300.86 \pm 0.73 \\
399.86 \pm 0.49\end{array}$ \\
\hline \multirow[t]{2}{*}{ Accuracy } & Spiked conc. $\left(\mu \mathrm{g} \mathrm{mL} \mathrm{L}^{-1}\right)$ & Recovery (\%), Mean \pm RSD (\%) \\
\hline & $\begin{array}{l}200.00 \\
300.00 \\
400.00\end{array}$ & $\begin{array}{l}99.80 \pm 0.47 \\
99.93 \pm 0.80 \\
99.62 \pm 0.58\end{array}$ \\
\hline
\end{tabular}

${ }^{\text {aWhere } y}=$ peak area, $x=$ concentration of drug in $\mu \mathrm{g} \mathrm{mL}^{-1}$ 


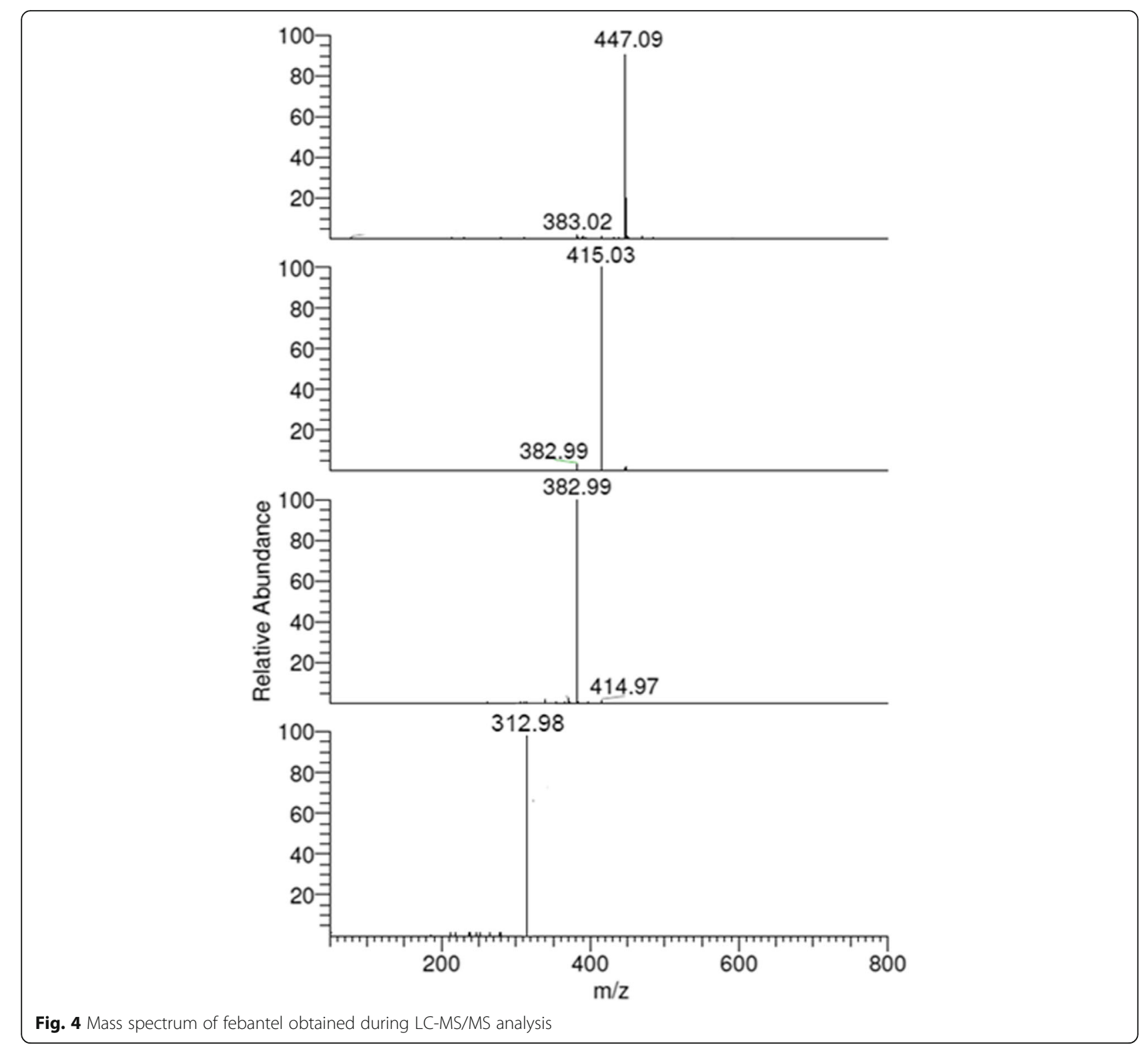

formate buffer solution (B) ( $\mathrm{pH}$ adjusted to 3.5 by using formic acid) in linear gradient mode $\left(T_{\min } / \mathrm{A}: \mathrm{B} ; T_{0.01} /\right.$ $\left.35: 65 ; T_{15} / 45: 55 ; T_{26} / 60: 40 ; T_{32} / 35: 65\right)$ with flow rate 1.0 $\mathrm{mL} / \mathrm{min}$. The result is depicted in Fig. 2. All degradation products were well resolved from adjacent peaks.

\section{Validation of developed stability indicating method Specificity and selectivity}

For every degradation condition, appropriate blank subjected to stress condition was kept and analyzed by HPLC. No interference was observed from blank at the retention time of drug as well as degradation products. The purity of peaks of degradation products and drug peak in a mixture of stressed samples was established through PDA studies. Data is depicted in Table 2.

\section{Linearity and range}

The linearity was established over the concentration range of 50 to $500 \mu \mathrm{g} \mathrm{mL}{ }^{-1}$. The values of slope and correlation coefficient $\left(r^{2}\right)$ were 39937 and 0.9996 respectively.

\section{Precision}

Precision was performed for intra-day and inter-day variations at three different concentration levels (200, 300, and $400 \mu \mathrm{g} \mathrm{mL} \mathrm{mL}^{-1}$ ). Evidently, the \% relative standard deviation (RSD) was found to be $<2.0$ in all 
cases confirming that the method was sufficiently reproducible.

\section{Recovery/accuracy}

Accuracy of the developed method was established through standard addition method where in recovery of pure drug spiked in degradation samples was calculated. Chromatogram is shown in Fig. 3. Acceptable recoveries were obtained at each concentration with mean recovery of $99.78 \%$.

Results of all method validation parameters are summarized in Table 3.

\section{Characterization of degradation products}

First, the drug febantel was subjected for LC-MS/MS analysis to understand fragmentation pathway of the drug. The resultant mass spectrum of the drug is depicted in Fig. 4.

The LC-MS/MS spectrum of all degradation products is depicted in Figs. 5 and 6.

Summary of LC-MS/MS data of drug and all five degradation products is provided in Table 4.

\section{In-silico ADME and toxicity study}

The drug and degradation products (DP-I to V) structures were submitted in SMILES format to AMDE-Tox online servers viz. SwissADME, OSIRIS property explorer, and ProTox-II webserver. For prediction of ADME properties and drug toxicity. The results of insilico studies are reported in Tables 5 and 6.

\section{Discussion}

\section{Degradation behavior}

Drug was found to degrade generating total five degradation products. They were labelled as DP-I, DP-II, DPIII, DP-IV, and DP-V in accordance with the elution order appeared in the chromatogram. DP-I was found to be major degradation product, which was generated under photolytic stress condition. Alkali (DP-II and DP-IV) and acid (DP-III and DP-V) hydrolysis generated two degradation products each, out of which one is major and other is small. Drug was observed to be stable under neutral hydrolysis, oxidative and thermal degradative conditions.

\section{Characterization of degradation products}

The molecular ion peak was observed at $m / z=447.09$, which was closely matching with exact mass of febantel $(m / z=447.13)$. The drug generated three fragments corresponding to $m / z$ values of $415.03,382.99$ and 312.98 . The first two fragments corresponding to $\mathrm{m} / \mathrm{z}$ value of 415.03 and 382.99 were formed due to conversion of two carbamate moieties to isocyanate one after another. The third fragment having $\mathrm{m} / \mathrm{z}$ value of 312.98 was formed due to cleavage of methoxy acetamide. The proposed fragmentation pathway of the drug is shown in Scheme 1.

\section{$D P-I(m / z$ 463.12)}

The DP-I was formed during photolytic degradation of drug. The molecular ion peak of DP-I was observed at $\mathrm{m} / \mathrm{z}$ value of 463.08 , which was exactly $16 \mathrm{amu}$ greater than that of drug febantel $(\mathrm{m} / z=447.09)$. It insinuated that there was addition of oxygen due to mild oxidation of drug under photolytic stress condition. Generally, compound forms $\mathrm{N}$-oxide/S-oxide under photolytic stress condition. The proposed structure for DP-I was predicted as $S$-oxide as other three fragments formed have $m / z$ value of $431.03,399.05$, and 329.01 which were exactly same as that of drug but have masses greater by $16 \mathrm{amu}$. It suggested that DP-I followed same fragmentation pathway as that of drug (refer Scheme 1). Sulfoxide formation also takes place by liver microsomes

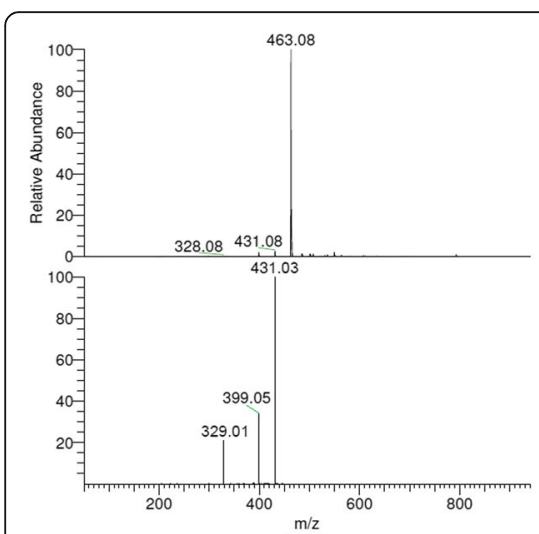

(a)

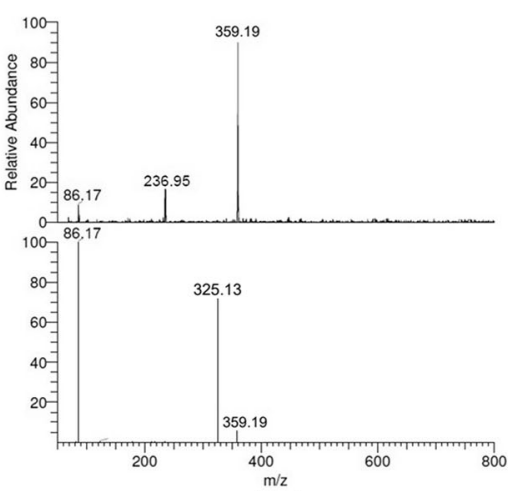

(b)

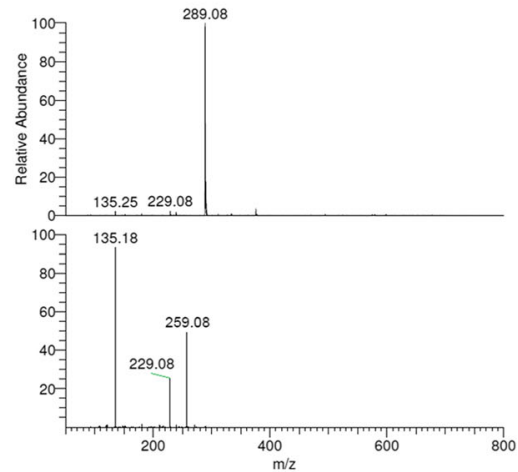

(c)

Fig. 5 LC-MS and LC-MS/MS spectra of a DP I, b DP ॥, and $\mathbf{c}$ DP III 


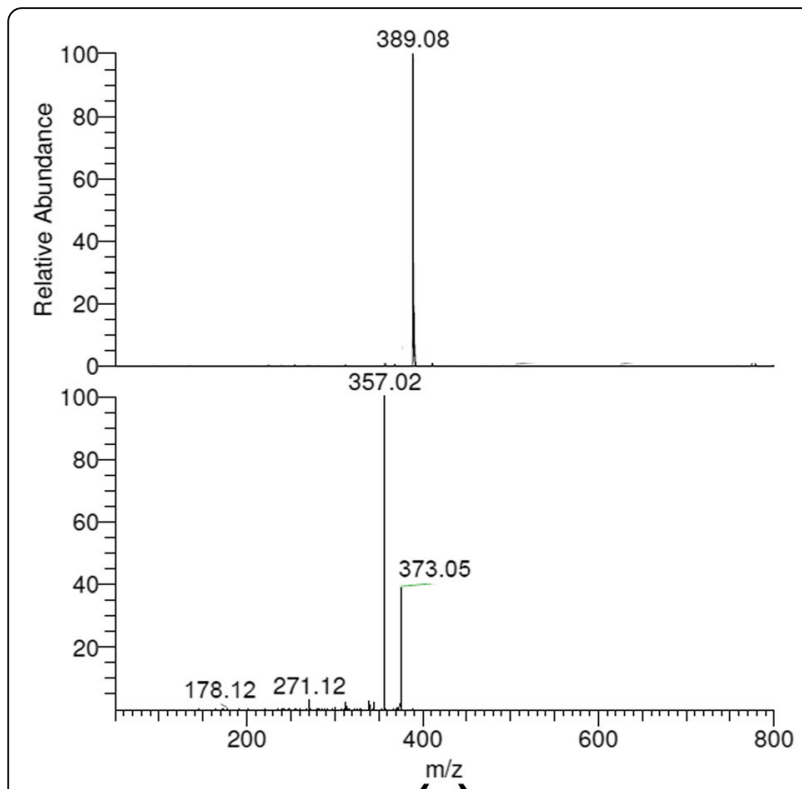

(a)

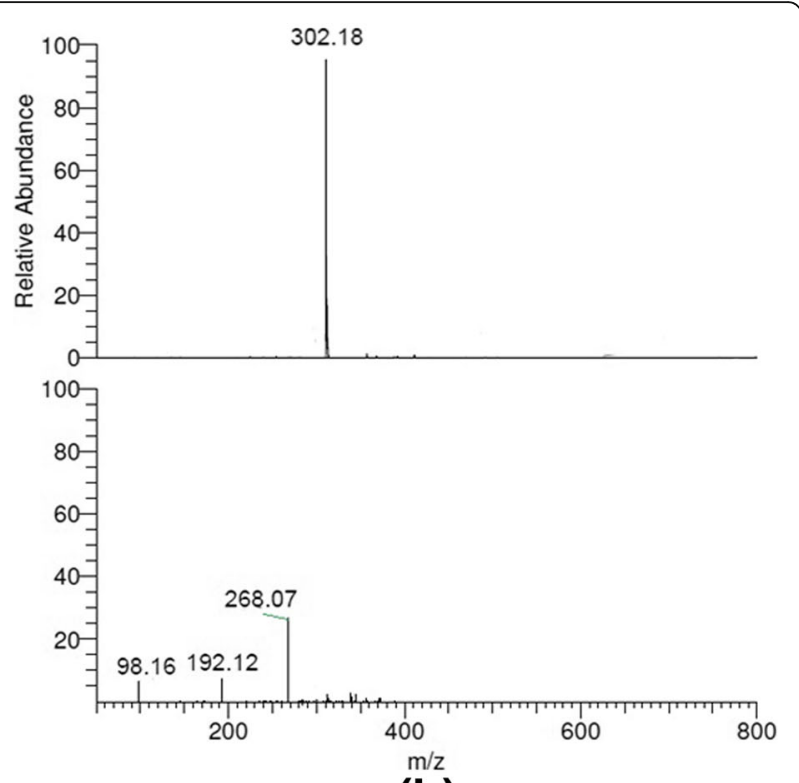

(b)

Fig. 6 LC-MS and LC-MS/MS spectra of a DP IV and $\mathbf{b}$ DP V

Table 4 Summary of LC-MS/MS data for drug and degradation products (DP I to V) with molecular formulae and major fragments

\begin{tabular}{|c|c|c|c|c|c|c|c|c|c|}
\hline \multirow[t]{2}{*}{ Compound } & \multirow{2}{*}{$\begin{array}{l}\text { Experimental } \\
\text { mass }\end{array}$} & \multirow{2}{*}{$\begin{array}{l}\text { Best possible } \\
\text { molecular } \\
\text { formula }\end{array}$} & \multirow{2}{*}{$\begin{array}{l}\text { Theoretical } \\
\text { mass }\end{array}$} & \multirow{2}{*}{$\begin{array}{l}\text { Error in } \\
\mathrm{mmu}\end{array}$} & \multirow[t]{2}{*}{ RDB } & \multicolumn{2}{|c|}{ Major fragments } & \multirow{2}{*}{$\begin{array}{l}\text { Error } \\
\text { in } \\
\text { mmu }\end{array}$} & \multirow{2}{*}{$\begin{array}{l}\text { Molecular formula } \\
\text { for best possible } \\
\text { fragments }\end{array}$} \\
\hline & & & & & & $\begin{array}{l}\text { Experimental } \\
\text { mass }\end{array}$ & Theoretical mass & & \\
\hline \multirow[t]{3}{*}{ Febantel } & 447.09 & $\mathrm{C}_{20} \mathrm{H}_{23} \mathrm{~N}_{4} \mathrm{O}_{6} \mathrm{~S}^{+}$ & 447.13 & -4.33 & 11.5 & 415.03 & 415.11 & -7.71 & $\mathrm{C}_{19} \mathrm{H}_{19} \mathrm{~N}_{4} \mathrm{O}_{5} \mathrm{~S}^{+}$ \\
\hline & & & & & & 382.99 & 383.08 & -9.09 & $\mathrm{C}_{18} \mathrm{H}_{15} \mathrm{~N}_{4} \mathrm{O}_{4} \mathrm{~S}^{+}$ \\
\hline & & & & & & 312.98 & 313.08 & -9.54 & $\mathrm{C}_{15} \mathrm{H}_{13} \mathrm{~N}_{4} \mathrm{O}_{2} \mathrm{~S}^{+}$ \\
\hline \multirow[t]{3}{*}{ DP-I } & 463.08 & $\mathrm{C}_{20} \mathrm{H}_{23} \mathrm{~N}_{4} \mathrm{O}_{7} \mathrm{~S}^{+}$ & 463.13 & -4.82 & 11.5 & 431.03 & 431.10 & -7.20 & $\mathrm{C}_{19} \mathrm{H}_{19} \mathrm{~N}_{4} \mathrm{O}_{6} \mathrm{~S}^{+}$ \\
\hline & & & & & & 399.05 & 399.08 & -2.58 & $\mathrm{C}_{18} \mathrm{H}_{15} \mathrm{~N}_{4} \mathrm{O}_{5} \mathrm{~S}^{+}$ \\
\hline & & & & & & 329.01 & 329.07 & -6.03 & $\mathrm{C}_{15} \mathrm{H}_{13} \mathrm{~N}_{4} \mathrm{O}_{3} \mathrm{~S}^{+}$ \\
\hline \multirow[t]{2}{*}{ DP-\| } & 359.19 & $\mathrm{C}_{17} \mathrm{H}_{19} \mathrm{~N}_{4} \mathrm{O}_{3} \mathrm{~S}^{+}$ & 359.12 & 7.28 & 10.5 & 325.13 & 325.08 & 5.46 & $\mathrm{C}_{16} \mathrm{H}_{13} \mathrm{~N}_{4} \mathrm{O}_{2} \mathrm{~S}^{+}$ \\
\hline & & & & & & 86.17 & 86.07 & 9.87 & $\mathrm{C}_{3} \mathrm{H}_{8} \mathrm{~N}_{3}{ }^{+}$ \\
\hline \multirow[t]{3}{*}{ DP-III } & 289.08 & $\mathrm{C}_{15} \mathrm{H}_{17} \mathrm{~N}_{2} \mathrm{O}_{2} \mathrm{~S}^{+}$ & 289.10 & -2.05 & 8.5 & 259.08 & 259.09 & -1.00 & $\mathrm{C}_{18} \mathrm{H}_{15} \mathrm{~N}_{2} \mathrm{OS}-$ \\
\hline & & & & & & 229.08 & 229.08 & 0.06 & $\mathrm{C}_{13} \mathrm{H}_{13} \mathrm{~N}_{2} \mathrm{~S}^{+}$ \\
\hline & & & & & & 135.18 & 135.09 & 8.83 & $\mathrm{C}_{8} \mathrm{H}_{11} \mathrm{~N}_{2}^{+}$ \\
\hline \multirow[t]{4}{*}{ DP-IV } & 389.08 & $\mathrm{C}_{18} \mathrm{H}_{21} \mathrm{~N}_{4} \mathrm{O}_{4} \mathrm{~S}^{+}$ & 389.13 & -4.78 & 10.5 & 373.05 & 373.13 & -8.29 & $\mathrm{C}_{18} \mathrm{H}_{21} \mathrm{~N}_{4} \mathrm{O}_{3} \mathrm{~S}^{+}$ \\
\hline & & & & & & 357.08 & 357.10 & -2.21 & $\mathrm{C}_{17} \mathrm{H}_{17} \mathrm{~N}_{4} \mathrm{O}_{3} \mathrm{~S}^{+}$ \\
\hline & & & & & & 271.12 & 271.08 & 4.21 & $\mathrm{C}_{14} \mathrm{H}_{13} \mathrm{~N}_{3} \mathrm{OS}^{+}$ \\
\hline & & & & & & 178.12 & 178.04 & 7.67 & $\mathrm{C}_{8} \mathrm{H}_{8} \mathrm{~N}_{3} \mathrm{~S}^{+}$ \\
\hline \multirow[t]{3}{*}{ DP-V } & 302.18 & $\mathrm{C}_{15} \mathrm{H}_{16} \mathrm{~N}_{3} \mathrm{O}_{2} \mathrm{~S}^{+}$ & 302.10 & 8.42 & 10.5 & 268.07 & 268.05 & 1.61 & $\mathrm{C}_{14} \mathrm{H}_{10} \mathrm{~N}_{3} \mathrm{OS}^{+}$ \\
\hline & & & & & & 192.12 & 192.02 & 9.74 & $\mathrm{C}_{8} \mathrm{H}_{6} \mathrm{~N}_{3} \mathrm{OS}^{+}$ \\
\hline & & & & & & 98.16 & 98.07 & 8.87 & $\mathrm{C}_{4} \mathrm{H}_{8} \mathrm{~N}_{3}{ }^{+}$ \\
\hline
\end{tabular}


Table 5 Results of in-silico ADME properties and toxicity data recorded for drug and degradation products using Swiss ADME

\begin{tabular}{lllllllll}
\hline Compound & GI & BBB & PgP & CYP1A2 & CYP2C19 & CYP2C9 & CYP2D6 & $\begin{array}{l}\text { CYP3A4 } \\
\text { inhhibitor } \\
\text { inhibitor }\end{array}$ \\
\hline Febantel & Low & No & No & No & Yes & Yes & No & No \\
DP-I & Low & No & Yes & No & Yes & Yes & No & No \\
DP-II & Low & No & No & No & Yes & Yes & No & No \\
DP-III & High & No & No & No & No & Yes & No & No \\
DP-IV & High & No & No & Yes & Yes & Yes & Yes & Yes \\
DP-V & Low & No & No & No & Yes & Yes & No & No \\
\hline
\end{tabular}

during conversion of febantel to oxfendazole and febantel sulfoxide is reported to be teratogenic in rats [5].

\section{$D P-I I(m / z 359.11)$}

The DP-II was formed during alkaline hydrolysis. The molecular ion peak of DP-II was observed at $m / z$ value of 359.19. The LC-MS/MS spectrum of DP-II is depicted in Fig. 5b. DP-II was formed due to loss of methoxy side chain and methoxy carbonyl moiety of the parent drug. DP-II was observed to generate first fragment of $\mathrm{m} / \mathrm{z}$ value of 325.13 likely due to loss of methyl group of the methoxy acetamido side chain and subsequent cyclization of side chain to form benzimidazole moiety. The third fragment (4,5-dihydro- $1 H$-imidazol-2amine) which was formed from second fragment due to cleavage of benzimidazole moiety was having $\mathrm{m} / \mathrm{z}$ value of 86.17. The detail fragmentation pathway is depicted in Scheme 1.

\section{DP-III $(\mathrm{m} / \mathrm{z} 289.10)$}

The DP-III was formed during acid degradation. The mass spectra of DP-III is shown in Fig. 5c. The molecular ion peak of DP-III was observed at $\mathrm{m} / z$ value of 289.08. It was formed via cleavage of two methyl carbamate side chain of the drug. Loss of carbamate is common in hydrolytic stress conditions as evident for almost all degradation products of febantel. The carbamate moiety is found in number of prodrugs and the rate and extent of its hydrolysis decides duration and intensity of the resultant pharmacological activity [32]. Further, it forms three fragments having $\mathrm{m} / \mathrm{z}$ values of 259.08 , 229.08 , and 135.18 by gradual cleavage of methoxy acetamide side chain; in addition to this, there was loss of phenyl ring attached to sulphur in the fragment of $m /$ $z$ 135.09. The detail fragmentation pattern is depicted in Scheme 2.

\section{DP-IV ( $\mathrm{m} / \mathrm{z}$ 389.12)}

The LC-MS spectrum of DP-IV is depicted in Fig. 6a while its fragmentation pattern is outlined in Scheme 2. DP-IV seems to be formed via loss of one of the methoxy carbonyl moiety from the drug as appearance of its parent ion peak at $389.08 \mathrm{~m} / z$. Three more fragments got formed from DP-IV having $\mathrm{m} / z$ value of 373.05 , 357.02, and 178.12. The fragment of $\mathrm{m} / z$ value 373.05 was formed due to loss of oxygen from methoxy acetamide side chain of DP-IV. Another fragment of $\mathrm{m} / \mathrm{z}$ 357.02 was formed due to conversion of one of the carbamate moieties to isocyanate and fragment with $\mathrm{m} / \mathrm{z}$ value of 178.12 was formed due loss of phenyl moiety attached to sulphur and subsequent cyclization to form benzimidazole moiety. The third fragment having $\mathrm{m} / \mathrm{z}$ value of 271.12 was formed from the fragment having $\mathrm{m} / \mathrm{z}$ value of 357.02 due to loss of methoxy acetamide side chain. This DP-IV which is chemically methyl [[2[(methoxyacetyl)amino]-4-(phenylsulfanyl) phenyl] carbamimidoyl] carbamate is official impurity A of febantel in European Pharmacopeia [2].

\section{$D P-V(m / z 302.09)$}

The DP-V was generated under acid hydrolysis. The parent ion peak was observed at $302.18 \mathrm{~m} / z$ (Fig. 6b). This degradation product was formed via cleavage of 2methoxyacetamide side chain and methoxy carbonyl

Table 6 Results of in-silico ADME properties and toxicity data recorded for drug and degradation products using OSIRIS Property Explorer

\begin{tabular}{|c|c|c|c|c|}
\hline Compounds & Mutagenic & Tumorigenic & Irritant & Reproductive effective \\
\hline Febantel & Nil & Nil & Nil & $\mathrm{Nil}$ \\
\hline DP-I & $\mathrm{Nil}$ & Nil & Nil & $\mathrm{Nil}$ \\
\hline DP-II & $\mathrm{Nil}$ & Nil & Nil & $\mathrm{Nil}$ \\
\hline DP-III & Medium Risk & Medium Risk & Nil & $\mathrm{Nil}$ \\
\hline DP-IV & $\mathrm{Nil}$ & Nil & Nil & $\mathrm{Nil}$ \\
\hline DP-V & Nil & Nil & Nil & Nil \\
\hline
\end{tabular}




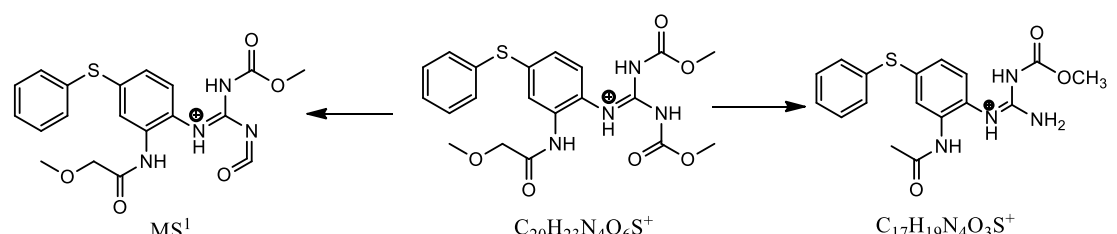

$\mathrm{C}_{19} \mathrm{H}_{19} \mathrm{~N}_{4} \mathrm{O}_{5} \mathrm{~S}^{+}$

Exact Mass: 415.1071<smiles>CCc1cc(NC(N=C=O)/N=C/O)c(NC(=O)COC)cc1Sc1ccccc1</smiles>

$\mathrm{MS}^{2}$

$\mathrm{C}_{18} \mathrm{H}_{15} \mathrm{~N}_{4} \mathrm{O}_{4} \mathrm{~S}^{+}$ Exact Mass: 383.0809<smiles>N#CCNC(=O)NC(=O)Nc1ccc(Sc2ccccc2)cc1N=O</smiles>
$\mathrm{MS}^{3}$

$\mathrm{C}_{15} \mathrm{H}_{13} \mathrm{~N}_{4} \mathrm{O}_{2} \mathrm{~S}^{+}$ Exact Mass: 313.0754

$$
\mathrm{C}_{20} \mathrm{H}_{23} \mathrm{~N}_{4} \mathrm{O}_{6} \mathrm{~S}^{+}
$$
Exact Mass: 447.1333

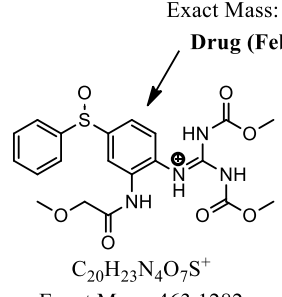

Exact Mass: 463.1282 Photo Degradant I (DP I)<smiles>COCC(=O)Nc1cc(C(=O)O[N+](=O)[O-])c(NC(=O)COC)cc1NC(NC=O)NC(=O)OC</smiles>
Exact Mass: 431.102

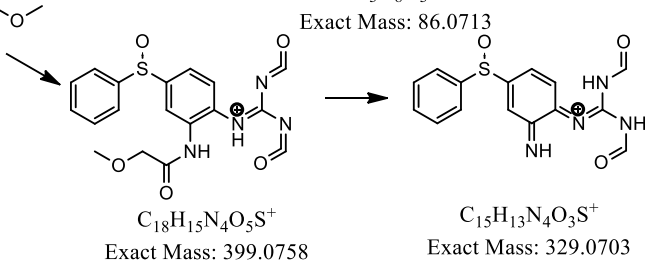

Scheme 1 Proposed mass fragmentation pathway of the drug and two degradation products

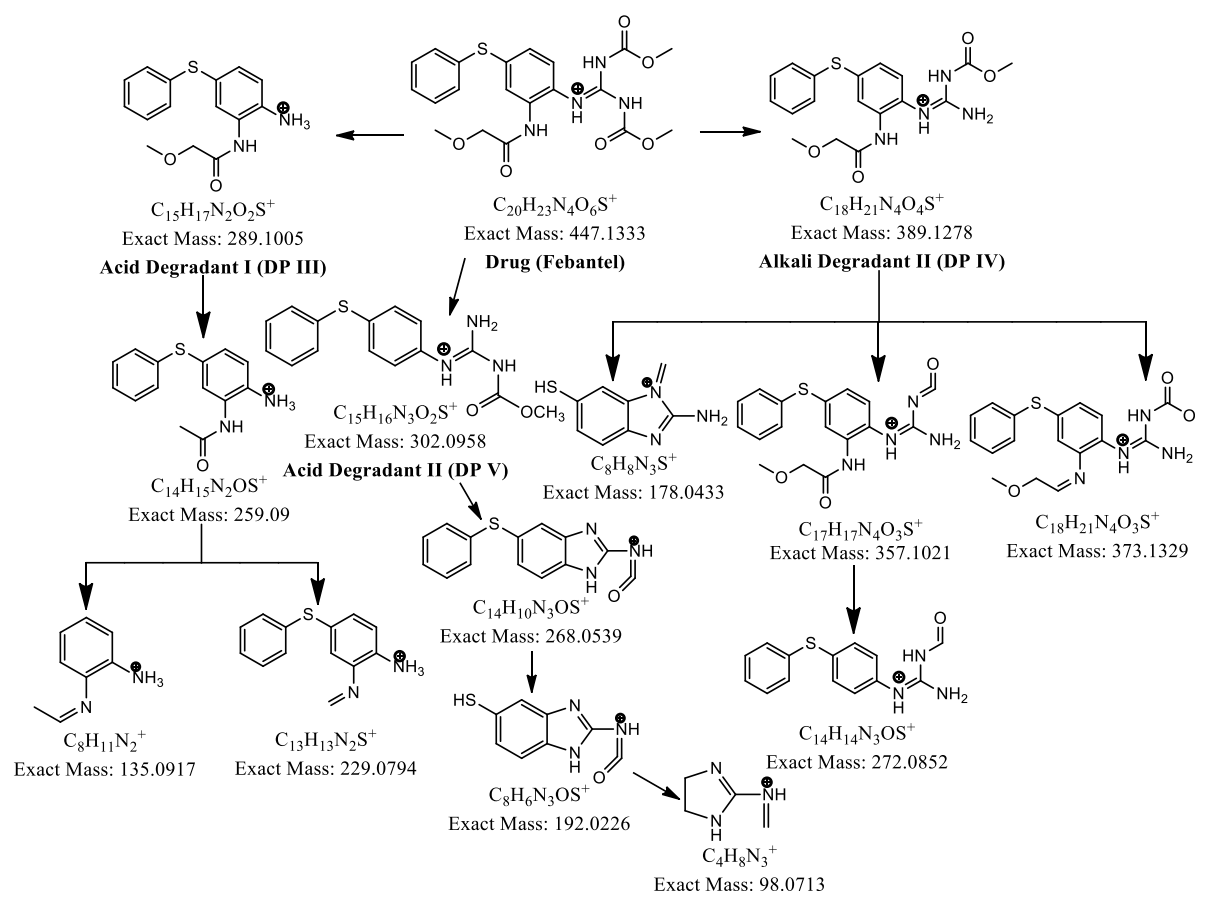

Scheme 2 Proposed mass fragmentation pathways of three degration products of febantel 
moiety from the drug. First fragment was formed due to cyclization to form benzimidazole moiety and conversion of side chain to isocyanate having $\mathrm{m} / \mathrm{z} 268.07$. Third fragment having $m / z 192.12$ was obtained via loss of aromatic ring attached to sulphur. Further fragmentation forms fourth fragment $(\mathrm{m} / \mathrm{z}$ 98.16) via loss of sulphur along with aromatic ring and loss of oxygen from isocyanate moiety. The proposed fragmentation pathway is depicted in Scheme 2.

The SwissADME tool computes key physicochemical, pharmacokinetic, drug-like, and related parameters from molecular structure. P-Glycoprotein (PgP) is the most important member among ATP-binding cassette transporters to affect transport of drug through biological membranes [33]. As per the results obtained in this study, DP-I is substrate for PgP while DP-III, IV, and V are predicted to have high gastrointestinal absorption. The ability to cross the blood-brain barrier (BBB) is low for all the DPs while they all are predicted to be CYP2C9 inhibitors. DP-I are DP-IV are predicted to inhibit CYP1A2 while DP-IV also additionally inhibits CYP2C19, CYP2D6, and CYP3A4.

OSIRIS Property Explorer programme is widely used in drug discovery to estimate the mutagenic, tumorigenic, irritant, and reproductive risks, and also provides information on the compound's hydrophilicity $(\log \mathrm{P})$, solubility $(\operatorname{LogS})$, molecular weight, druglikeness, and drug score. The DPs were run through the OSIRIS Property Explorer; only DP-III showed moderate risk of being a mutagenic and tumorigenic; however, the Pro Tox II Predictions cleared all the DPs for any sort of toxicity viz. hepato-toxicity, carcinogenicity, immuno-toxicity mutagenicity, and cysto-toxicity [34-36].

\section{Conclusion}

Febantel was subjected to ICH recommended stress degradation studies to assess its susceptibility under various respective forced degradation conditions.

The drug was found to be sensitive to acidic, basic, photolytic conditions, whereas it was resistant to degrade in neutral, oxidative, and thermal stress. Chromatographic separation indicated generation of five degradation products. One degradation product formed under photolytic stress condition was denoted as (DP-I). DP-II and DPIV were formed in alkaline hydrolytic condition while DP-III and DP-V were formed in acidic stress condition. Characterization of all the DPs was done by LC-MS/MS studies. Presented study revealed important information that is not yet available with respect to stability of febantel such as (a) degradation profile of febantel under common degradative conditions, (b) mass fragmentation pathway of drug as well as its DPs, and (c) ADME and toxicity potential of drug and formed DPs.

\section{Supplementary Information}

The online version contains supplementary material available at https://doi. org/10.1186/s43094-020-00138-7.

Additional file 1. Supplementary Material for Characterization and Toxicity Evaluation of Degradation Products of Febantel. HPLC chromatograms along with chromatographic conditions for all stress degradations of febantel and during optimization of stability indicating method development, optimized MS parameters for fragmentation.

\section{Abbreviations}

ACN: Acetonitrile; DP: Degradation products; DAD: Diode array detector; ICH: International Conference on Harmonization; LC-MS/MS: Liquid chromatography-mass spectrometry; RDB: Ring plus Double Bond; RRT: Relative retention time; RSD: Relative standard deviation

\section{Acknowledgments}

The authors wish to thank Veritas, India for gift sample of febantel.

\section{Authors' contributions}

Conceptualization: AAM, VTG. Design of the work: AAM, AMM. Formal Analysis and Investigation: AMM, SSJ. LC-MS and toxicological study: RP. Writing —original draft preparation: AAM. Writing—review and editing: VTG. Supervision of work: VTG. All authors read and approved the final manuscript.

\section{Funding}

No funding was received for this work.

\section{Availability of data and materials}

Data and material are available upon request.

Ethics approval and consent to participate Not applicable.

\section{Consent for publication}

Not applicable.

\section{Competing interests}

The authors declare that they have no competing interests.

\section{Author details}

${ }^{1}$ Department of Pharmaceutical Analysis, Goa College of Pharmacy, Panjim 403 001, Goa, India. ²Department of Pharmaceutical Chemistry, Sinhgad Institute of Pharmacy, Narhe, Pune 411041, Maharashtra, India.

Received: 19 March 2020 Accepted: 2 November 2020

Published online: 09 December 2020

\section{References}

1. Indian Pharmacopoeia (2014) Veterinary monographs, vol IV. Indian Pharmacopoeia Commission, Ghaziabad, p 3522

2. European Pharmacopoeia, 9.0 (2018) Strasburg: European Directorate for the Quality of Medicines and Health Care (EDQM), Council of Europe, vol 2018, p 2450

3. Sweetman SC (2007) Martindale: the complete drug reference. Pharmaceutical Press, London

4. Riviere JE, Papich MG (2017) Veterinary pharmacology and therapeutics. Wiley, Hoboken

5. Febantel, WHO food additives series, 29. http://www.inchem.org/ documents/jecfa/jecmono/v29je03.htm. Accessed 08 Oct 2020.

6. Rose MD (1999) Analyst 124:1023

7. Ben-Zvi Z, Gussarsky E, van Creveld C, Yagil R (1996) J Vet Pharmacol Ther 19(4):288-294. https://doi.org/10.1111/j.1365-2885.1996.tb00051.x

8. Bialecka W, Kulik A (2010) Acta Pol Pharm Drug Res 67:463

9. Sajjanwar R, Bhaskaran S, Kakati K, Jha SK (2014) J Appl Pharm Res 2:32-43

10. Dusi G, Gamba V, Faggionato E (2005) J Pharm Biomed Anal. https://doi. org/10.1016/j.jpba.2005.01.010

11. Su SC, Chou HH, Chang PC, Liu CH, Chou SS (2004) J Food Drug Anal 12: 244-253 
12. Delatour P, Tiberghien MP, Besse S (1983) J Vet Pharmacol Ther. https://doi. org/10.1111/j.1365-2885.1983.tb00469.x

13. Danaher M, Ruyck H, Crooks SR, Dowling G, O'Keeffe M (2007) J Chromatogr B Anal Technol Biomed Life Sci. https://doi.org/10.1016/j.jchromb.2006.07. 046

14. Residues of some veterinary drugs in animals and foods (1991) FAO food and nutrition paper, 41/4 http://www.fao.org/3/T0500E/T0500E.pdf. Accessed 13 Mar 2020

15. Landuyt J, Debackere M, Delbeke F, McKellar Q (1993) Biomed Chromatogr. https://doi.org/10.1002/bmc.1130070206

16. Horvat AJM, Babic S, Pavlovic DM, Asperger D, Pelko S, Kastelan-Macan M, Petrovic M, Mance AD (2012) Trends Anal Chem. https://doi.org/10.1016/j. trac.2011.06.023

17. Babić S, Pavlovic DM, Biosic M, Asperger D, Skoric I, Runje (2018) Environ Sci Pollut Res Int 25:28917-28927. https://doi.org/10.1007/s11356-018-2935-9

18. Wilson RT, Groneck JM, Henry AC, Rowe LD (1991) J Assoc Off Anal Chem 74:56-67

19. Whelan M, Kinsella B, Furey A, Moloney M, Cantwell H, Lehotay SJ, Danaher M (2010) J Chromatogr A. https://doi.org/10.1016/j.chroma.2010.05.007

20. Martinez Vidal JL, Garrido Frenich A, Aguilera-Luiz MM, Romero-Gonzalez R (2010) Anal Bioanal Chem. https://doi.org/10.1007/s00216-009-3425-1

21. Pontes FLD, Pontarolo R, Campos FR, Gasparetto JC, Cardoso MA, Piantavini MS, Trindade ACLB (2013) Asian J Pharm Clin Res 6:191-200

22. Kumble D, Badiadka N (2016) J Assoc Arab Univ Basic Appl Sci. https://doi. org/10.1016/j.jaubas.2014.06.005

23. Piantavini MS, Pontes FLD, Cerqueira LB, Peralta-Zamora PG, Pontarolo R (2014) J Anal Chem. https://doi.org/10.1134/S1061934814100104

24. Piantavini MS, Pontes FLD, Uber CP, Stremel DP, Sena MM, Pontarolo R (2014) Spectrochim Acta A Mol Biomol Spectrosc. https://doi.org/10.1016/j. saa.2014.01.078

25. Silva MDS, Gonring KL, Silva RCS, Fonseca MC, Borges MMC, Nunes OC, Forim MR, Borges KB, Borgesa WDS (2018) Quim Nova. https://doi.org/10. 21577/0100-4042.20170168

26. Pelko S, Horvat Alka JM, Mance AD, Babic S, Kaštelan-Macan M (2009) HPLC analysis for detection of albendazole, febantel and levamisole hydrochloride and their photodegradation products. Pharmaceuticals and their degradation products in environment, Poster $33 \mathrm{https}: / / w w w . b i b . i r b . h r / 432$ 030. Accessed 13 Mar 2020

27. Cizmic M, Ljubas D, Škorićc I, Rožman M, Ašperger D, Curković L, Petrović M, Babić S (2018) Desalin Water Treat. https://doi.org/10.5004/dwt.2018.21915

28. Asperger D, Papac J, Čizmić M, Babić S, Landeka DT, Ljubas D, Ćurković L, Radman S (2017) J Chromatogr Sep Tech. https://doi.org/10.4172/21577064-C1-032

29. International Conference on Harmonization of Technical Requirements for Registration of Pharmaceuticals for Human Use (2003) ICH harmonized tripartite guideline, Topic Q1A (R2), Geneva

30. International Conference on Harmonization of Technical Requirements for Registration of Pharmaceuticals for Human Use (1996) ICH harmonized tripartite guideline, Topic Q1B, Geneva

31. International Conference on Harmonization of Technical Requirements for Registration of Pharmaceuticals for Human Use (2005) ICH harmonized tripartite guideline, Topic Q2(R1), Geneva

32. Ghosh AK, Brindisi M (2017) J Med Chem. https://doi.org/10.1021/jm501371s

33. Daina A, Michielin O, Zoete V (2016) Sci Rep. https://doi.org/10.1038/ srep42717

34. Sander T, Freyss J, Von Korff M, Reich JR, Rufener C (2009) J Chem Inf Model. https://doi.org/10.1021/ci800305f

35. Puratchikody A, Sriram D, Umamaheshwari A, Irfan N (2016) Chem Cent J. https://doi.org/10.1186/s13065-016-0169-9

36. Oduselu GO, Ajani OO, Ajamma YU, Brors B, Adebiyi E (2019) Bioinform Biol Insights. https://doi.org/10.1177/1177932219865533

\section{Publisher's Note}

Springer Nature remains neutral with regard to jurisdictional claims in published maps and institutional affiliations.

\section{Submit your manuscript to a SpringerOpen ${ }^{\circ}$ journal and benefit from:}

- Convenient online submission

- Rigorous peer review

- Open access: articles freely available online

- High visibility within the field

- Retaining the copyright to your article

Submit your next manuscript at $\boldsymbol{\nabla}$ springeropen.com 